\title{
Kamu Hastanelerinde Çalışan Başhekim ve Sağlık Bakım Hizmetleri Müdürlerinin İletişim Becerilerine Yönelik Tanımlayıcı Bir Araştırma
}

\author{
Hanife Tiryaki Şen ${ }^{1} \odot$, Şehrinaz Polat ${ }^{2} \oplus$, Nihal Ünaldı Baydınْ, \\ Ayda Uzunçarşılı Soydaş̧ ${ }^{4}$
}

1'istanbul Sağlık Müdürlüğü, Sağlık Hizmetleri Başkanlığı, İstanbul, Türkiye

${ }^{2}$ Istanbul Üniversitesi İstanbul Tıp

Fakültesi Hastanesi, Hemşirelik

Hizmetleri Bölümü, İstanbul, Türkiye

${ }^{3}$ Ondokuz Mayıs Üniversitesi Sağılk

Bilimleri Fakültesi, Hemşirelik

Bölümü, Samsun, Türkiye

${ }^{4}$ Marmara Üniversitesi, İletişim

Fakültesi, İstanbul, Türkiye

Hanife Tiryaki Şen, Dr.

Şehrinaz Polat, Dr.

Nihal Ünaldı Baydın, Dr. Öğr. Üyesi

Ayda Uzunçarşılı Soydaş, Prof. Dr.

İletişim:

Dr. Hanife Tiryaki Şen

İstanbul Sağık Müdürlüğü, Sağlık Hizmetleri

Başkanlığı, İstanbul, Türkiye

Tel: +90505478 4485

E-Posta: hanifetiryaki@gmail.com

\section{ÖZET}

Amaç: Bu araştırma hastane yöneticilerinin kendi iletişim becerilerine yönelik bakış açılarııı ortaya koymak amacıyla tanımlayııı tasarımda gerçekleştirildi.

Hastalar ve Yöntem: Araştırmanın evrenini İstanbul'daki 6 Kamu Hastaneler Birliğine bağlı 56 hastanede görevli başhekim ve sağık bakım hizmetleri müdürü, örneklemini ise, araştırmaya katılmayı kabul eden 41 başhekim ve 42 sağlık bakım hizmetleri müdürü olmak üzere toplam 83 hastane yöneticisi oluşturdu. Araştırmanın verileri Kişisel Bilgi Formu ve İletişim Becerileri Ölçeği kullanılarak toplandı. Verilerin değerlendirilmesinde tanımlayıı istatistiksel analizlerin yanı sıra Student t testi, Mann Whitney U testi ve ilişkilerin değerlendirilmesinde Pearson Korelasyon Analizi, Spearman's Korelasyon Analizi kullanıldı.

Bulgular: Araşııımanın sonucunda, yöneticilerin Iletişim Becerileri Ölçeği alt boyutlarından aldıkları puanlara göre en yüksek alınan ilk üç boyut sırasıyla lletişim İlkeleri ve Temel Beceriler alt boyutu, Etkin Dinleme ve Sözel Olmayan Iletiş̧im alt boyutu, Iletişim Kurmaya İsteklilik alt boyutu olduğu belirlendi. Ölçekten alınan en düşük puan ortalamasının Kendini Iffade etme alt boyutuna ait olduğu saptandı. Bağımsız değişkenler ile ölçek puan karşıllaştırmalarında ise ölçeğin Iletişim Illkeleri ve Temel Beceriler alt boyut puan ortalamasııın medeni duruma göre istatistiksel olarak anlamlı farkılık olduğu $(p<0,05)$, medeni durumu evli olan yöneticilerin Iletişim İlkeleri ve Temel Becerilerden aldıkları puan ortalamasının bekâr olan yöneticilere göre daha yüksek olduğu belirlendi.

Sonuç: Yöneticilerin iletişim ilkeleri ve temel becerileri konusunda iyi oldukları, kendilerini iyi ifade ettikleri, iletişim kurmaya istekli oldukları, etkin dinleme ve sözel olmayan iletişim kurmada iyi oldukları sonucuna ulaşılmıştır.

Anahtar sözcükler: Iletişim, iletişim becerileri, başhekim, sağık bakım hizmetleri müdürü, hastane

\section{COMMUNICATION SKILLS OF PUBLIC HOSPITAL MANAGERS AND HEALTH CARE DIRECTORS A DESCRIPTIVE STUDY}

\section{ABSTRACT}

Objectives: This study was carried out in a descriptive concept so as to investigate the self-communication skills of hospital managers.

Patients and Methods: The universe of the study consisted of Chief Physicians and Healthcare Directors working in 56 affiliated hospitals with 6 Public Hospitals Union in Istanbul. The sample consisted of 41 Chief Physicians and 42 Healthcare Directors voluntarily participated which is a total of 83 managers. Data were collected by administering Personal Information Form and the Communication Skills Scale. In data analysis, in addition to descriptive statistics Student's t-test and Mann-Whitney U test were used, Pearson's and Spearman's Correlation Analysis methods were used in examining the relationships between variables.

Results: According to the score of the hospital managers gained from Sub-dimensions of the Communication Skills Scale, it was determined that the three dimensions that gained the highest score were Communication Principles and Basic Skills Sub-dimension, Effective Listening and Nonverbal Communication Sub-dimension, Willingness to Contact Sub-dimension, respectively. It was determined that the lowest average point gained from the scale was related to Express Yourself Subdimension. In comparisons between independent variables and score of scale, there was a statistically significant difference between the average point of Communication Principals and Basic Skills Sub-dimension and marital status $(p<0.005)$ and average point of married managers gained from Communication Principles and Basic Skills Sub-dimension was higher than the average point of single managers.

Conclusion: It has been achieved that managers are good at communication principles and basic skills, they are good at expressing themselves, they are willing to communicate, they are good at effective listening and non-verbal communication.

Keywords: Communication, communication skills, chief physician, health care director, hospital
Gönderilme Tarihi : 30 Kasım 2018

Revizyon Tarihi : :06 Mayıs 2019

Kabul Tarihi : 15 Temmuz 2019 
ağlık sektöründeki hızlı değişim ve gelişmeler, rekabet koşulları, kaynakların sınırlılığı gibi nedenler, düşük maliyetli ve kaliteli sağlık hizmetlerini zorunlu kılmaktadır. Bu nedenle, yönetim bilgi, becerisine sahip profesyonel yöneticiler ön plana çıkmaktadır (1). Bir sistem olarak iletişim olgusunun en büyük amacı ilişkilerin belirli bir düzen içine sokulması ve böylelikle örgütsel amaçlarla bireysel amaçlar arasında bilinçli bir dengenin kurulmasıdır. Yöneticilerin başarısı ve örgütlerin etkinliği üzerinde rol oynayan iletişim sürecinin örgütlerde işler hale getirilmesi-yöneticilerin en önemli işleri arasındadır $(2,3)$. Illetişim, bir kurum içerisinde etkili, verimli bir şekilde gerçekleşmesi gereken, üst-ast ilişkilerini belirleyen, beraberinde başarıyı, anlayışı, sağlıklı bir örgüt iklimini getiren bir süreçtir. Yönetici açısından bakıldığında ise iletişim becerileri, insanlarla etkileşim içindeyken onları çalıştırma becerileri olarak kabul edilmektedir (4).

Literatürde iletişim becerilerinin sözel olan ve olmayan mesajlara duyarlılık, etkili dinleme ve tepki verme sözel, bedensel, dokunsal, hareket içeren mesajlar şeklinde olabildiği belirtilmektedir. Bireylerin kişilikleri, iletişimin gerçekleştiği ortam, iletişimin içeriği ve önemi, kültürel yapı, iletişimle ilgili ilkelere uyup uymama, etkili iletişim becerilerini kullanma ve sözel ya da sözel olmayan mesajların kullanımı iletişimi etkilemektedir (5).

Yöneticinin etkili iletişim kurabilmesi için; iletişim kurulacak grubun özelliklerini bilmesi örgütsel amaçlarla uyumlu olan iletişim stratejilerini geliştirmesi, yürütmesi ve etkili diyaloglar kurması gerekmektedir. Yöneticilerin konuşmalarındaki etkileme yeteneği, astların kurum amaçlarını daha iyi benimsemesini sağlamaktadır (6). Yöneticiler iletişim sürecini, çalışan davranışlarını değiştirme, örgütte haberleşme ağlarını kurma, kişiler ve gruplar arası ilişkileri geliştirme, yetkisi kapsamındaki işleri gerçekleştirme amaçlarıyla kullanmaktadırlar (4). Yapılan bir çalışmada, çalışanları destekleyici etkili iletişim ortamının yaratılmasının hemşirelerin onur ve saygınlık algısını arttırdığı, soru sormasını ve yardım istemesini destekleyen bir çalışma ortamı yaratıı̆ı ifade edilmektedir. Yönetici hemşirelerin sürekli kritik eder tarzda ve sert tonda konuşmasının çalışanlar üzerindeki iletişim etkinliğini azalttığı, bu nedenle örgütteki güven ve saygınlık kültürünü olumsuz etkilediği, diğer sağlık çalışanlarının önünde yapılan geri beslemelerin hemşirelerin utanmasına ve iş verimlerinin düşmesine sebep olduğu bildirilmektedir (7).

Örgütlerde yöneticiler ve liderlerin, iletişimlerini uygun düzeyde tutması işe devam, üretkenlik, çalışan morali gibi çıktılar açısından da olumlu sonuçlara katkıda bulunmaktadır $(8,9)$. Tükenmişlik sendromu ve iletişim alanında yapılmış olan çalışmalar iş verimliliği açısından ciddi bir tehdit olan tükenmişlik sendromunun iletişim ile ilişkili olduğunu ortaya koymaktadır (10). Iletişim eğitimleri ile sağlanan iletişim etkinliğinin tükenmişlik sendromunu azaltmada etkili ve pahalı olmayan bir yol olduğu, iş verimliliği, iş performansı nt ve sağlık hizmetlerindeki kaliteyi arttırdığı belirtilmektedir (11).

İyi bir iletişim sürecinin örgütlerde kurulması iletişimin önemine inanmış yöneticilere ve yöneticilerin sorumlulukları yüklenmelerine bağlıdır (2). Hastane yöneticilerinin hastanenin tüm iç ve dış paydaşları ile kurduğu iletişimde kullandığı iletişim tarzları ve iletişim becerileri, iş tatmini, memnuniyet ve kaliteli hizmet verme açısından büyük önem taşımaktadır (12). Yönetici hemşireler ile yapılan bir çalışma da yönetici pozisyonunda çalışanların liderlik biçimlerinin, iletişim becerileri, kendi farkındalıkları formal ve informal iletişim etkinliklerini arttırmada önemli olduğu, çalışanların örgütsel vatandaşlığını ve işte daha iyi sonuçlar elde etmelerini etkilediği belirtilmektedir. İletişim zayıflığının bakım kalitesini doğrudan etkilediği bu nedenle bu konudaki sorumluluğun etkili bir iletişim ortamı ve süreci yaratması açısından yöneticilere ait olduğu ifade edilmektedir (13). Hemşireler ile yapılan bir araştırmada, iletişim becerilerini artırmaya yönelik eğitim alan hemşirelerin yüksek iş tatminine sahip olduğu görülmektedir (14). Verimsiz iletişim becerileri sağlık hizmeti çıktılarının kalitesini olumsuz olarak etkilemektedir. Bu nedenle tüm sağlık çalışanlarının iletişim becerilerini arttıran eğitimlerle güçlendirilmeleri hasta ilişkilerinde kolaylık ve iş performanslarında artış sağlayacaktır. Bunun için de yöneticilerin etkin iletişimin önemini kavraması ve iletişim ortamını geliştirmesi önemlidir Hastanelerde hizmet üreten insan gücünü yöneten pozisyonlarda çalışan Başhekim ve Sağlık Bakım Hizmetleri Müdürlerinin iletişim becerileri sağlık çalışanlarını doğrudan etkilemektedir ve bireysel amaçların kurumsal amaçlara dönüştürülmesinde önem arz etmektedir.

\section{Yöntem}

Bu çalışmanın amacı, kamuda görev yapan başhekim ve sağlık bakım hizmetleri müdürlerinin iletişim beceri düzeylerinin belirlenmesidir. Çalışma tanımlayıcı ve kesitsel olarak planlanmıştır.

\section{Araştırmanın problem cümlesi}

$\mathrm{Bu}$ araştırmada aşağıdaki araştırma sorularına yanıt aranmıştır; 
Kamuda görev yapan başhekim ve sağlık bakım hizmetleri müdürlerinin iletişim beceri düzeyleri nedir?

Başhekim ve sağlık bakım hizmetleri müdürlerinin iletişim beceri düzeyleri sosyodemografik özelliklere göre farklılık göstermekte midir?

\section{Araştırmanın evreni ve örneklemi}

Araştırmanın evrenini İstanbul ilindeki 56 kamu hastanenin başhekim ve sağlık bakım hizmetleri müdürleri oluşturdu ( $\mathrm{N}=112)$. Araştırmada örneklem seçimine gidilmedi. Veriler Şubat-Mayıs 2015 tarihleri arasında kendisine ulaşılabilen, araştırmaya katılmayı gönüllü olarak kabul eden ve anket formlarını eksiksiz dolduran 41 Başhekim ve 42 sağlık bakım hizmetleri müdürü olmak üzere toplam 83 yöneticiden toplandı.

\section{Veri toplama araçları}

Araştırmanın verileri anket yöntemi ile toplandı. Veriler, kişisel ve çalışma yaşamına ilişkin özellikleri içeren Kişisel ve Mesleki Bilgi Formu (yaş, cinsiyet, meslek, görevde ve meslekte çalışma süresi, yönetim eğitimi alma durumu) ve Illetişim Becerileri Ölçeği kullanılarak toplandı.

\section{Illetişim becerileri ölçeği}

Ölçek Korkut Owen ve Bugay (2014) tarafından oluşturulmuştur. Beşli Likert tarzında (1: Hiçbir zaman; 2: Bazen; 3: Nadiren; 4: Sıklıkla; 5: Her zaman) olup 25 ifade ve dört alt boyuttan oluşmaktadır. Alt boyutlar, Iletişim Ilkeleri ve Temel Beceriler (10 ifade), Kendini ifade Etme (4 ifade), Etkin Dinleme ve Sözel Olmayan Illetişim (6 ifade) ve Illetişim Kurmaya İsteklilik (5 ifade) şeklindedir. Ölçeğin değerlendirmesi alt boyutlar ve toplam ölçek puanı üzerinden yapılmaktadır. Ölçek alt boyutları ve ölçek toplamından alınan puanın yüksek olması iletişim becerisinin yüksek olduğunugöstermektedir. Ölçeğin kesme noktası yoktur ve olumsuz ifadeler bulunmamaktadır. Korkut Owen ve Bugay (2014) ölçek güvenilirlik çalışmasında Cronbach alfa katsayısını 0,88 bulurken; bu çalışmada, alt boyutlar ve ölçeğin Cronbach alfa katsayısı 0,57 ile 0,90 arasında bulunmuştur.

\section{Verilerin değerlendirilmesi}

İstatistiksel analizler için NCSS (Number Cruncher Statistical System) programı kullanıldı. Çalışma verileri değerlendirilirken tanımlayıcı istatistiksel analizlerin (ortalama, standart sapma, sıklık) yanı sıra normal dağılım gösteren değişkenlerin gruplar arası karşılaştırmalarında Student $\mathrm{t}$ test, normal dağılım göstermeyen değişkenlerin karşılaştırmalarında Mann Whitney $U$ test kullanıldı.
Parametreler arası ilişkilerin değerlendirilmesinde de Pearson Korelasyon Analizi ve Spearman Korelasyon Analizi kullanıldı.

\section{Araştırmanın etik yönü ve uygulanması}

Araştırmanın yapılabilmesi için ölçeği geliştiren Fidan Korkut Owen ve Aslı Bugay'dan ölçek kullanım izni İstanbul Medipol Üniversitesi Girişimsel Olmayan Klinik Araştırmalar Etik kurulundan, 12/12/2014 tarih ve 10840098-340 sayılı etik kurul onayı ve araştırmanın yapıldığı hastanelerden de yazılı izinler alındı. Katılımcılara kimliklerinin gizli tutulacağı ve verilerin yalnızca araştırma için kullanılacağı açıklandı. Katılımcılara araştırma konusunda bilgi verilerek onamları alındı. Veri toplama formları katılımcılara verildi ve doldurmaları istendi. Veri toplama formlarının doldurulması yaklaşık 15-20 dakika sürdü.

\section{Araştırmanın sınırlııkları}

Bu araştırmanın bulguları gönüllü olarak katılım sağlayan örneklem grubu ile sınırlıdır, tüm başhekim ve yönetici hemşirelere genellenemez. Veri toplamada anket yönteminin kullanılması bir diğer kısıt olup, katılımcıların anket sorularını cevaplarken doğru cevap verdiği kabul edilmektedir.

\section{Bulgular}

$\mathrm{Bu}$ çalışmada katılımcıların \%44,6'sının erkek, $\% 55,4$ 'ünün kadın ve tamamına yakınının $(\% 90,4)$ evli

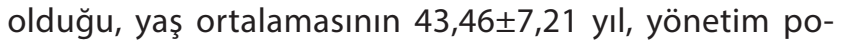

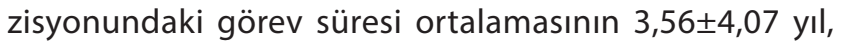
meslekteki görev süresi ortalamasının $21,47 \pm 6,53$ yıl olduğu bulundu. Katılımcıların \%49,4'ünün Başhekim, \%50,6'sının Sağlık Bakım Hizmetleri Müdürü pozisyonunda çalıştığı \%10,8'inin profesör, \%12'sinin doçent, \%25,3'ünün uzman doktor, \%31,3'ünün hemşire, \%20 ,5'inin ise uzman hemşire unvanına sahip olduğu, $\% 86,7$ 'sinin yönetim konusunda eğitim aldığı belirlendi. (Tablo1). Katılımcıların Illetişim Becerileri Ölçeği toplam ve alt boyutlarından aldıkları puanlara bakıldığında, Kendini ifade Etme alt boyut puan ortalamasının 4,32 $\pm 0,44$ Etkin Dinleme ve Sözel Olmayan Iletişim alt boyut puan ortalamasının4,25 $\pm 0,42$, Iletişim Illkeleri ve Temel Beceriler alt boyut puan ortalamasının4,19 $\pm 0,41$ iletişim Kurmaya Isteklilik alt boyut puan ortalamasının 4,09 $\pm 0,41$ ve ölçek toplam puan ortalamasının $4,21 \pm 0,36$ olduğu bulundu (Tablo 2).

Illetişim Becerileri Ölçeğinin "iletişim Illkeleri ve Temel Beceriler" alt boyutu puan ortalamasının medeni duruma 
Tablo 1. Katılımcıların sosyo-demografik özelliklerine ilişkin bulguların dağılımı $(n=83)$

\begin{tabular}{|c|c|c|c|}
\hline & & Min-Maks & Ort $\pm S D$ \\
\hline Yaş (yıl) & & $30-58$ & $43,46 \pm 7,21$ \\
\hline $\begin{array}{l}\text { Yönetimdeki } \\
\text { görev süresi (yıl) }\end{array}$ & & 1 ay -23 yll & $3,56 \pm 4,07$ \\
\hline \multirow[t]{2}{*}{$\begin{array}{l}\text { Meslekte } \\
\text { görev süresi (yıl) }\end{array}$} & & $8-35$ & $21,47 \pm 6,53$ \\
\hline & & $N$ & $\%$ \\
\hline \multirow[t]{2}{*}{ Cinsiyet } & Erkek & 37 & 44,6 \\
\hline & Kadın & 46 & 55,4 \\
\hline \multirow[t]{2}{*}{ Medeni durum } & Evli & 75 & 90,4 \\
\hline & Bekar & 8 & 9,6 \\
\hline \multirow[t]{2}{*}{ Görevi } & Başhekim & 41 & 49,4 \\
\hline & Sağlık bakım müdürü & 42 & 50,6 \\
\hline \multirow[t]{5}{*}{ Akademik unvan } & Prof. Dr. & 9 & 10,8 \\
\hline & Doç. Dr. & 10 & 12,0 \\
\hline & Uzman doktor & 21 & 25,3 \\
\hline & Hemşire & 26 & 31,3 \\
\hline & Uzman hemşire & 17 & 20,5 \\
\hline \multirow{2}{*}{$\begin{array}{l}\text { Yönetim konusunda } \\
\text { eğitim durumu }\end{array}$} & Eğitim almış & 72 & 86,7 \\
\hline & Eğitim almamış & 11 & 13,3 \\
\hline
\end{tabular}

Tablo 2. Katıımcıların iletişim becerileri ölçeği alt boyutları ve ölçek toplamından aldıkları puan ortalamaları $(n=83)$

\begin{tabular}{lc} 
İletişim becerileri ölçek alt boyutları & Ort \pm SD \\
\hline Illetişim ilkeleri ve temel beceriler & $4,19 \pm 0,41$ \\
Kendini ifade etme & $4,32 \pm 0,44$ \\
İletişim kurmaya isteklilik & $4,09 \pm 0,41$ \\
Etkin dinleme ve sözel olmayan iletişim & $4,25 \pm 0,42$ \\
Toplam ölçek puanı & $4,20 \pm 0,50$
\end{tabular}

göre istatistiksel olarak anlamlı farklılık gösterdiği $(p<0,05)$, evli olan yöneticilerin Iletişim Ilkeleri ve Temel Beceriler alt boyut puanının anlamlı düzeyde yüksek olduğu bulundu. Katılımcıların çalıştığı pozisyon ve yönetim konusunda eğitim alma durumlarına göre iletişim becerileri ölçeği ölçek toplam ve tüm alt boyutlar arasında istatistiksel olarak anlamlı farklılık belirlenmedi ( $p>0,05)$, (Tablo 3 ). Katılımcıların yaş grupları, yönetimdeki görev süreleri, mesleki çalışma yılları ile Illetişim Becerileri Ölçeği alt boyut ve toplam ölçek puanları arasında istatistiksel olarak anlamlı bir ilişki saptanmadı ( $p>0,05)$, (Tablo 4).

Tablo 4. İletişim becerileri ölçek toplam ve alt boyut puan ortalamalarının yaş, yönetimdeki görev süreleri ve mesleki deneyim durumları arasındaki ilişki

\begin{tabular}{|c|c|c|c|c|c|c|}
\hline $\begin{array}{l}\text { İletişim Becerileri } \\
\text { Ölçeği Alt Boyutları }\end{array}$ & $Y_{a}$ & aş & $\begin{array}{l}\text { Yönet } \\
\text { Görev }\end{array}$ & $\begin{array}{l}\text { imdeki } \\
\text { Süreleri }\end{array}$ & $\begin{array}{l}\text { Mes } \\
\text { Dene }\end{array}$ & $\begin{array}{l}\text { leki } \\
\text { eyim }\end{array}$ \\
\hline & $r^{c}$ & $P$ & $r^{d}$ & $P$ & $r^{c}$ & $P$ \\
\hline $\begin{array}{l}\text { İletişim Illkeleri ve } \\
\text { Temel Beceriler }\end{array}$ & $-0,073$ & 0,509 & $-0,073$ & 0,509 & $-0,068$ & 0,542 \\
\hline Kendini Ifade Etme & $-0,037$ & 0,739 & $-0,037$ & 0,739 & $-0,043$ & 0,697 \\
\hline İletişim Kurmaya İsteklilik & 0,032 & 0,776 & 0,032 & 0,776 & 0,026 & 0,812 \\
\hline $\begin{array}{l}\text { Etkin Dinleme ve Sözel } \\
\text { Olmayan Illetişim }\end{array}$ & $-0,152$ & 0,171 & $-0,152$ & 0,171 & $-0,152$ & 0,169 \\
\hline $\begin{array}{l}\text { Toplam Ölçek Puan } \\
\text { Ortalaması }\end{array}$ & $-0,078$ & 0,483 & $-0,078$ & 0,483 & $-0,086$ & 0,437 \\
\hline
\end{tabular}

\section{Tartışma}

Yöneticilerin, iletişim becerileri aracılığıyla çalışanlar arasındaki ilişkileri geliştirmeleri, karşııılı güven oluşturup olumlu çalışan davranışları ortaya çıkartarak bireysel ve

Tablo 3. Katıımcıların iletişim becerileri ölçeği alt boyutları ve ölçek toplamından aldıkları puan ortalamalarının ile medeni durumları, görevleri ve yönetim eğitimi alma durumlarına göre karşıllaştıııması $(\mathrm{n}=83)$

\begin{tabular}{|c|c|c|c|c|c|c|c|c|c|c|c|c|c|c|c|}
\hline \multirow{4}{*}{$\begin{array}{l}\text { İletişim } \\
\text { Becerileri } \\
\text { Ölçeği Alt } \\
\text { Boyutları }\end{array}$} & \multicolumn{4}{|c|}{ Görevi } & $a p$ & \multicolumn{4}{|c|}{ Medeni Durumu } & $b p$ & \multicolumn{4}{|c|}{ Yönetim Konusunda Eğitim Alma Durumu } & $b p$ \\
\hline & \multirow{2}{*}{\multicolumn{2}{|c|}{$\begin{array}{c}\text { Başhekim } \\
(n=41)\end{array}$}} & \multirow{2}{*}{\multicolumn{2}{|c|}{$\begin{array}{c}\begin{array}{c}\text { Sağlık Bakım } \\
\text { Hizmetleri Müdürü }\end{array} \\
(n=42)\end{array}$}} & & \multirow{2}{*}{\multicolumn{2}{|c|}{$\begin{array}{c}\text { Evli } \\
(n=75)\end{array}$}} & \multirow{2}{*}{\multicolumn{2}{|c|}{$\begin{array}{l}\text { Bekar } \\
(n=8)\end{array}$}} & & \multirow{2}{*}{\multicolumn{2}{|c|}{$\begin{array}{c}\text { Eğitim Almış } \\
(n=72)\end{array}$}} & \multirow{2}{*}{\multicolumn{2}{|c|}{$\begin{array}{c}\text { Eğitim Almamış } \\
(n=11)\end{array}$}} & \\
\hline & & & & & & & & & & & & & & & \\
\hline & Min-Max & $O r t \pm S D$ & Min-Max & $O r t \pm S D$ & & Min-Max & $O r t \pm S D$ & Min-Max & Ort $\pm S D$ & & Min-Max & $O r t \pm S D$ & Min-Max & $O r t \pm S D$ & \\
\hline $\begin{array}{l}\text { İletişim Illkeleri ve } \\
\text { Temel Beceriler }\end{array}$ & $1,90-5,0$ & $4,18 \pm 0,47$ & $3,0-4,80$ & $4,20 \pm 0,34$ & 0,852 & $1,90-5,0$ & $4,21 \pm 0,41$ & $3,70-4,80$ & $4,01 \pm 0,34$ & $0,021^{*}$ & $3,60-5,0$ & $4,23 \pm 0,30$ & $1,90-4,70$ & $3,90 \pm 0,79$ & 0,384 \\
\hline $\begin{array}{l}\text { Kendini Ifade } \\
\text { Etme }\end{array}$ & $2,50-5,0$ & $4,39 \pm 0,46$ & $3,0-5,0$ & $4,26 \pm 0,42$ & 0,211 & $2,50-5,0$ & $4,34 \pm 0,46$ & $4,0-4,50$ & $4,18 \pm 0,17$ & 0,105 & $3,0-5,0$ & $4,37 \pm 0,37$ & $2,50-4,75$ & $4,02 \pm 0,70$ & 0,109 \\
\hline $\begin{array}{l}\text { İletişim Kurmaya } \\
\text { İsteklilik }\end{array}$ & $2,60-5,0$ & $4,11 \pm 0,46$ & $3,2-5,0$ & $4,06 \pm 0,34$ & 0,58 & $2,60-5,0$ & $4,10 \pm 0,42$ & $3,40-4,40$ & $4,0 \pm 0,30$ & 0,556 & $3,20-5,0$ & $4,11 \pm 0,37$ & $2,60-5,0$ & $3,94 \pm 0,59$ & 0,36 \\
\hline $\begin{array}{l}\text { Etkin Dinleme ve } \\
\text { Sözel Olmayan } \\
\text { Illetişim }\end{array}$ & $2,67-5,0$ & $4,22 \pm 0,47$ & $3,5-5,0$ & $4,28 \pm 0,37$ & 0,486 & $2,67-5,0$ & $4,27 \pm 0,42$ & $3,67-5,0$ & $4,10 \pm 0,43$ & 0,167 & $3,33-5,0$ & $4,28 \pm 0,39$ & $2,67-5,0$ & $4,10 \pm 0,62$ & 0,554 \\
\hline $\begin{array}{l}\text { Toplam Ölçek } \\
\text { Puan Ortalaması }\end{array}$ & $2,32-4,92$ & $4,21 \pm 0,41$ & $3,28-4,76$ & $4,19 \pm 0,29$ & 0,836 & $3,32-4,9$ & $4,22 \pm 0,36$ & $3,72-4,64$ & $4,06 \pm 0,27$ & 0,067 & $3,72-4,92$ & $4,23 \pm 0,28$ & $2,32-4,76$ & $3,98 \pm 0,62$ & 0,264 \\
\hline
\end{tabular}


kurumsal bazda yüksek performans elde etmeleri önemlidir $(15,16,17)$. Bu bağlamda kamu hastanelerinde görev yapan başhekim ve sağlık bakım hizmetleri müdürlerinin iletişim becerileri düzeylerinin ortaya konduğu bu çalışmadan elde edilen bulgular sonucunda, Kamu Hastanelerinde görev yapan başhekim ve sağlık bakım hizmetleri müdürlerinin iletişim temel becerileri ölçek toplam puan ortalamasının $4,21 \pm 0,36$ ve Kendini Ifade Etme alt boyut puan ortalamasının 4,32 $\pm 0,44$ Etkin Dinleme ve Sözel Olmayan Iletişim alt boyut puan ortalamasının $4,25 \pm 0,42$ olması nedeniyle, etkin dinleme konusunda kendilerini yeterli, sözel olmayan iletişim konusunda da kendilerini iyi gördükleri, çalışanlar ve iş arkadaşlarıyla iletişim kurma konusunda istekli oldukları dolayısıyla genel olarak değerlendirildiğinde iletişim becerilerinde kendilerini yeterli gördükleri söylenebilir. Karadağ ve ark.'nın (2015) hekim ve hemşireler üzerinde yaptıkları çalışmada, hekimlerin \%81,1'inin, hemşirelerin \%83,5'inin etkin bir iletişim becerisine sahip olduğu bildirilmiştir (18).

Araştırmada iletişim becerileri alt boyutlarının tümü ortalamanın üzerindedir. Kendini Ifade Etme alt boyut puan ortalamasının 4,32 $\pm 0,44$ Etkin Dinleme ve Sözel Olmayan Iletişim alt boyut puan ortalamasının 4,25 $\pm 0,42$, Iletişim ilkeleri ve Temel Beceriler alt boyut puan ortalamasının $4,19 \pm 0,41$ iletişim Kurmaya Isteklilik alt boyut puan ortala-

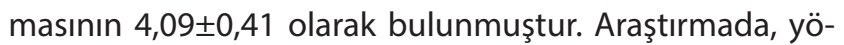
neticilerin iletişim becerileri alt boyutlarından ortalaması en düşük olan iletişim kurmaya isteklilik alt boyutudur. Sağlık hizmeti ortamlarında güvenliği sağlamak için iletişim kurma isteği önemlidir (19). Iletişim kurmaya istekli olan astlar, üstleri ile yukarı doğru iletişim kurmaya daha yatkın olduğu (20) gibi yöneticilerin de iletişim kurmaya istekli olması, çalışanlarla ve dış çevre ile etkin bir iletişimi sağlamayı kolaylaştıracaktır. Etkili iletişim becerileri, disiplinlerarası ekibin tüm üyeleri için önemli bir yeterliliktir (19). Uluslararası Hemşireler Konseyi'ne (ICN) göre (1990) hemşire yöneticilerin, hemşirelik hizmeti sunumunu geliştirmek, etkili iletişim ve planlama yapabilmek için disiplinler arası iletişim ağı oluşturması ve sürdürmesi gerekliliği ifade edilmektedir (21). Bu bağlamda dünyada yönetici hemşirelere ihtiyaca göre eğitimler düzenlenmesine rağmen Türkiye'de yönetici hemşirelere yönelik eğitimlere ve bu konuda yapılan çalışmalara rastlanılmamıştır. İletişim becerileri konusunda Hagemeier ve ark. (2014), çalışmalarında, iletişim kursunun hemşirelik, tıp ve eczacılık öğrencilerinin kişilerarası ve mesleklerarası iletişimlerini pozitif etkilediğini bildirmiştir (22). Ayrıca yapılan bir çalışmada eğitim yoluyla iletişim becerileri arttırılmış doktor ve hemşirelerin günlük karşılaştıkları iletişim odaklı işleri başarılı yönetme yeterliliklerinin arttığı ortaya çıkmıştır (23).
Çalışmada evli olan yöneticiler, bekar olanlara göre Illetişim ilkeleri ve Temel Becerileri yönünden daha yüksek puan almışlardır. Bu durum evli olan yöneticilerin eşler arasındaki iletişimin sağlıklı sürdürülebilmesi açısından iletişim kurma, sürdürme gibi iletişimin temel becerileri konusunda daha duyarlı ve hassas olabileceklerini düşündürmektedir. Kumcağız ve diğerlerinin (2011) bir çalışmasında ise hemşirelerin medeni durumlarına göre iletişim becerileri düzeyleri ve alt boyutları arasındaki farkın istatistiksel olarak anlamlı olmadığı bulunmuştur (24). Oyur, Mercan, Şaylan ve Buran'ın (2012)'de yaptıkları çalışmada duyguları ifade etme ve iletişim becerileri arasında pozitif yönde anlamlı ilişki bulunduğu, evli olanların bekar olanlara göre zihinsel ve duygusal iletişim becerilerinin yüksek olduğu bulunmuştur (25). Bu çalışmada da evli olan katılımcılar bekar olanlara göre Iletişim ilkeleri ve Temel Becerileri boyutundan yüksek puan almışlardır.

Bu çalışmada katılımcıların yaş, yönetimdeki görev süreleri, mesleki çalışma yılları, çalıştığı pozisyon ve yönetim konusunda eğitim alma durumlarına göre iletişim becerileri ölçeği toplam ve tüm alt boyutlar arasında istatistiksel olarak anlamlı farklılık bulunmamıştır. Karadağ ve ark.'nın (2015), çalışmalarında, hekimlerde akademik unvan, kurumdaki toplam çalışma süresi ve meslekten genel memnuniyet düzeyi; hemşirelerde ise eğitim düzeyi değişkenlerinin ve her iki grup için de yaş ve meslekteki toplam çalışma süresi değişkenlerinin iletişim becerileri üzerinde anlamlı etkiye sahip olduğu bildirilmişken (18) bu çalışmada anlamlı etkiye sahip olmadığı bulunmuştur. Uğurlu ve ark.'nın (2012), eğitim alanındaki denetçiler üzerinde yapılan bir araştırmada ise iletişim becerilerinde cinsiyet ve kıdem değişkenleri açısından anlamlı bir fark bulunmadığı bildirilmiştir (26). Bu çalışmada da anlamlı bir fark olmadığı bulunmuş olup çalışmanın bulgusunu desteklemektedir. Önler ve ark.'nın (2018), sağlık çalışanları üzerinde yaptıkları bir çalışmaya göre, iletişim becerileri puanı yaş, iş tecrübesi ve aynı ünitedeki çalışma yılı ile artmakta olduğu ifade edilmiştir. (27). Bu çaış̧mada ise katılımcıların iletişim becerileri puanı ile yaş, görev süresi ve mesleki çalışma yılı arasında istatistiksel olarak anlamlı bir fark bulunmamıştır. Karimzadeh ve ark.'nın (2017), sağlık yönetimi lisans eğitimi öğrencilerinde yapılan bir çalışmada öğrencilerin iletişim becerileri ile cinsiyet, medeni durum, doğum yeri (kentsel veya kırsal) ve ikamet dahil demografik değişkenler arasındaki karşılaştırmada anlamlı bir farklılık göstermediği, ancak en genç öğrenci grubu olan 18 ve 20 yaş arasındaki öğrencilerin daha yaşlı olanlardan daha az iletişim becerisine sahip olduğu bildirilmiştir (28). Yöneticilerin görev süreleri ile ölçek toplam ve alt boyutlar arasında herhangi 
bir ilişki tespit edilemezken Kumcağız ve diğerleri (2011) hemşirelerin çalışma yılının genel iletişim beceri düzeylerini etkilediğini, 20 yıl ve üzeri çalışan hemşirelerin iletişim beceri düzeylerinin daha yüksek olduğu sonucuna ulaştıkları saptanmıştır (24).

Rajesh ve Suganthi, (2013) tarafından öğretmenler ile yapılan bir çalışmada, öğretmenlerin yöneticilerinin kişilerarası iletişim becerilerinden memnuniyetinin öğretmenlerin tükenme düzeyi ile olumsuz yönde ilişkili olduğunu ortaya koymaktadır (29). Ayrıca, yönetici seçiminde iletişim becerisi önemli bir seçim kriteri haline geldiği (30) göz önünde bulundurularak, hastane yöneticilerinin seçiminde iletişim becerisi yüksek olan yöneticilerin tercih edilmesi, hastanenin etkin ve verimli yönetilmesinde faydalı olabilecektir. Gelecek çalışmalarda hastane yöneticilerinin iletişim becerisinden memnuniyetini etkileyen farklı faktörlerin incelenmesi yanısıra, hastane çalışanlarının yöneticilerinin iletişim becerilerinden memnuniyeti ve ilişkili olabilecek kurumsal sonuçlar konusunda araştırmaların yapılması yararlı olacaktır.

\section{Kaynaklar}

1. Tengilimoğlu D, Işık O, Akbolat M. Sağlık İşletmeleri Yönetimi, 8. Basım. Ankara: Nobel Akademik Yayıncılık; 2012. s.339-44.

2. Vergiliel Tüz M,Sabuncuoğlu Z. Örgütsel Psikoloji, 4. Baskı. Bursa: Alfa Aktüel Basım Yayıncılık; 2008. s.115-51.

3. Atak M. Örgütlerde resmi olmayan iletişimin yeri ve önemi. Havacılık ve Uzay Teknolojileri Derg 2005;2:59-67.

4. Fidan $M$, Küçükali R. İlköğretim kurumlarında yöneticilerin iletişim becerileri ve örgütsel değerler. Eğitim Bilimleri Araştırmaları Derg 2014;4:317-34. https://dergipark.org.tr/tr/download/ article-file/697066

5. Korkut Owen F, Bugay A. Illetişim becerileri ölçeği'nin geliştirilmesi: Geçerlilik ve güvenirlik çalışması. Mersin Üniversitesi Eğitim Fakültesi Derg 2014;10:51-64. https://dergipark.org.tr/tr/download/ article-file/161046

6. Tanrıverdi H, Adıgüzel O, Çiftçi M. Sağlık yöneticilerine ait iletişim becerilerinin çalışan performansına etkileri: Kamu hastanesi örneği. Süleyman Demirel Üniversitesi Sosyal Bilimler Enstitüsü Derg 2010;1:101-22. https://dergipark.org.tr/tr/download/ article-file/215502

7. Rouse RA, Al-Maqbali M. Identifying nurse managers' essential communication skills: An analysis of nurses' perceptions in oman. J Nurs Manage 2014;22:192-200. [CrossRef]

8. Özarallı N, Torun A. Biçimsel ve biçimsel olmayan iletişim, yönetici ile kuruma duyulan güven ve üstün uzmanlık gücü arasındaki ilişkiler üzerine bir araştırma. Bilgi Ekonomisi ve Yönetimi Derg 2011;4:10113. https://dergipark.org.tr/tr/download/article-file/40417

9. İş̧̧i $E, B a l$ Taştan $S$, Akyol Ç. Örgütsel güvenin işe yabancılaşma üzerindeki etkisinde yöneticinin iletişim becerisinin rolü: Özel hastane çalışanları örneği. Uluslararası Hakemli Beşeri ve Akademik Bilimler Derg 2013;2:95-113. https://arastirmax.com/tr/system/files/ dergiler/160806/makaleler/2/3/arastrmx_160806_2_pp_95-113.pdf

\section{Sonuç ve Öneriler}

Bu araştırmada yöneticilerin iletişim ilkeleri ve temel beceriler konusunda iyi oldukları, kendilerini iyi ifade ettikleri, iletişim kurmaya istekli oldukları, etkin dinleme ve sözel olmayan iletişim kurmada iyi oldukları, genel olarak ise iletişim becerileri konusunda kendilerini yeterli gördükleri sonucuna ulaşılmıştır. İletişim süreci, yönetim sisteminin karmaşık özelliği nedeniyle özellikle örgütlerde yöneticiler için önemli bir yönetim aracıdır. Bu sonuçlar doğrultusunda hastanelerde İletişim Becerileri eğitiminin hizmet içi eğitim programlarında yer alması ve katııımın yönetici pozisyonlarında görevli olanların yanı sıra tüm çalışanları kapsaması ve işe yeni başlayanlar için alınması zorunlu eğitimler içinde bulunması önerilebilir. Ayrıca yöneticilere yönelik hastanelerde yöneticilerin kendileri ve çalışanları açısından çeşitli konularda farkındalıklarının ve iletişim becerilerinin geliştirmelerine katkı sağlaması açısından belirli aralıklarla Duyarlııı Eğitimleri düzenlenmesi önerilebilir.

\section{Teşekkür}

Çalışmaya katılan tüm Sağlık Bakım Hizmetleri Müdürlerine ve Başhekimlere teșekkür ederiz.

10. Ahmadi A, Ahmadi M, Elyasi F, Ahmadi N. The relationship of occupational burnout and communication skills in nurses. J Mazand Univ Med Sci 2013:23:130-9.

11. Darban F, Balouchi A, Narouipour A, Safarzaei E, Shahdadi H. Effect of communication skills training on the burnout of nurses: A crosssectional study. J Clin Diagn Res 2016;10:1-4. [CrossRef]

12. Can $A$, İbicioğlu $H$. Yönetim ve yöneticilik yönünden üniversite hastanelerinin değerlendirilmesi. Süleyman Demirel Üniversitesi İktisadi ve İdari Bilimler Fakültesi Derg 2008;13:253-75. https:// dergipark.org.tr/tr/download/article-file/194720

13. Riggio RE, Taylor SJ. Personality and communication skills as predictors of hospice nurse performance. J Bus Pschol 2000;15:3519. [CrossRef]

14. Kalliope K, Koutra A, Koumoundourou G. Nurses' Communication Skills: Exploring Their Relationship with Demographic Variables and Job Satisfaction in A Greek Sample. Procedia - Soc Behav Sci 2011;30:2230-4. [CrossRef]

15. Bucata G, Rizescu AM. The Role of communication in enhancing work effectiveness of an organization. Land Forces Acad Rev 2017;22:49-57. [CrossRef]

16. Kelvin-Iloafu LE. The role of effective communication in strategic management of organizations. Int J Hum Soc Sci 2016;6:93-9. https://www.researchgate.net/publication/327212629_THE_ROLE_ OF_EFFECTIVE_COMMUNICATION_IN_STRTEGIC_MANAGEMENT_ OF_ORGANIZATIONS

17. Borca C, Baesu VA. Possible managerial approach for internal organizational communication characterization. Procedia - Soc Behav Sci 2014;124:496-503. [CrossRef]

18. Karadağ $\mathrm{M}$, Işık $\mathrm{O}$, Cankul Hi, Abuhanoğlu H. Hekim ve hemşirelerin iletişim becerilerinin değerlendirilmesi. Gazi Üniversitesi İktisadi ve İdari Bilimler Fakültesi Derg 2015;17:160-79. https://dergipark.org. tr/tr/download/article-file/287195 
19. Payton J. Improving communication skills within the nephrology unit. Nephrol Nurs J 2018;45:269-72. https://pubmed.ncbi.nlm.nih. gov/30304620/

20. Kamal Kumar K, Kumar Mishra S. Subordinate-superior upward communication: Power, politics and political skill. Human Resource Manage 2017;56:1015-37. [CrossRef]

21. ICN. Preparation of nurse managers and nurses in general health management. International Council of Nurses Publication, Geneva, 1990.

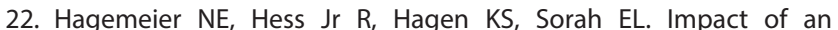
Interprofessional communication course on nursing, medical and pharmacy students. Communication Skill Self-Efficacy Beliefs. Am J Pharm Educ 2014;78:1-10. [CrossRef]

23. Ammentorp J, Sabroe S, Kofoed PE, Mainz J. The effect of training in communication skills on medical doctors' and nurses' self-efficacy a randomized controlled trial. Patient Educ Couns 2007;66:270-7. [CrossRef]

24. Kumcağız H, Yılmaz M, Balcı Çelik S, Aydın Avcı I. Hemşirelerin iletişim becerileri: Samsun ili örneği. Dicle Tıp Derg 2011;38:49-56. https:// dergipark.org.tr/tr/download/article-file/54225

25. Oyur E, Mercan N, Şaylan O, Buran AÇ. İş ortamında duyguları ifade etme ve iletişim becerileri üzerine bir araştırma. Organizasyon ve Yönetim Bilimleri Derg 2012;4:97-106. https://dergipark.org.tr/tr/ download/article-file/151008
26. Uğurlu M, Eğici MT, Yıldırım O, Örnek $M$, Üstü Y. Aile hekimliği uygulamasında güncel problemler ve çözüm yolları-2. Ankara Med J 2012;12:4-10. https://dergipark.org.tr/tr/download/ article-file/19734

27. Önler E, Yildiz T, Bahar S. Evaluation of the communication skills of operating room staff. J Interprof Educ Pract 2018;10:44-6. [CrossRef]

28. Karimzadeh S, Rezaee R, Bastani P. A study of communication skills in health care management students and its association with demographic characteristics. J Health Manage Inform 2017;4:40-3. https://pdfs.semanticscholar.org/afd1/ d667b98b44d44be1b8d26db49336ac7f35a0.pdf

29. Rajesh JI, Suganthi L. The satisfaction of teachers with their supervisors' interpersonal communication skills in relation to job burn-out and growth satisfaction in southern India. Manage Educ 2013;27:128-37. https://eric.ed.gov/?id=EJ1019639

30. Bambacas M, Patrickson M. Assessment of communication skills in manager selection: some evidence from Australia. J Manage Dev 2009;28:109-20. [CrossRef] 